International Journal of Physical Modelling in Geotechnics

Volume 14 Issue 4

Centrifuge study on the cyclic performance of caissons in sand

Cox, O'Loughlin, Cassidy et al.

\title{
Centrifuge study on the cyclic performance of caissons in sand
}

James A. Cox MEng

Postgraduate Student, Department of Civil Engineering, University of Bristol, UK

Conleth D. O'Loughlin PhD

Associate Professor, Centre for Offshore Foundation Systems, University of Western Australia, Crawley, Australia

Mark Cassidy DPhil, FIEAust, FTSE

Professor/Director, Centre for Offshore Foundation Systems, University of Western Australia
Subhamoy Bhattacharya PhD (Cantab)

Professor, Department of Civil and Environmental Engineering, University of Surrey, Guildford, UK

Christophe Gaudin MEng, PhD

Professor/Deputy Director, Centre for Offshore Foundation Systems, University of Western Australia, Crawley, Australia

Britta Bienen Diplng, PhD

Associate Professor, Centre for Offshore Foundation Systems, University of Western Australia, Crawley, Australia

Suction caissons are currently considered as an alternative to monopile foundations for met masts and offshore wind turbines. This paper presents the results of a series of centrifuge tests conducted on cyclically loaded suction caissons in very dense dry sand. Two representative caisson foundations were modelled at a 1200 scale in a geotechnical centrifuge and were subjected to a number of different cyclic loading regimes, for up to 12000 cycles, both of which add to previous data sets available in the literature. During each test, changes in stiffness, the accumulation of rotation and settlement of the system were measured. It was found that the rotational caisson stiffness increased logarithmically with the number of loading cycles, but to a much lower extent than previously reported for monopiles. Similarly the accumulation of rotation was also observed to increase with number of cycles and was well described using a power relationship. An aggregation of rotation was also observed during two-way tests and is believed to be caused by the initial loading cycles that create a differential stiffness within the local soil. Predictions were then made as to the behaviour of a prototype structure based upon the observed test results and established influence parameters.

\section{Notation}

$A_{\mathrm{k}}$

$D$

$D_{\mathrm{r}}$

$D_{50}$

$E_{\mathrm{s}}$

$e_{\max }$

$e_{\min }$

$G_{\mathrm{r}}$

$H$

K

$K_{0}$

$k$

$M$

$M_{\max }$

$M_{\min }$

$M_{\mathrm{R}}$

$N$

$P_{\mathrm{a}}$

$T$ stiffness change parameter

caisson diameter $(\mathrm{m})$

relative density of sand $(\%)$

mean sand grain diameter $(\mathrm{mm})$

Young's modulus of caisson skirt (MPa)

maximum void ratio

minimum void ratio

shear modulus of soil at a depth of $\mathrm{D} / 2$

(MPa)

horizontal load on foundation (N)

unloading stiffness $(\mathrm{Nm} / \mathrm{rad})$

characteristic non-dimensional foundation stiffness

instantaneous non-dimensional foundation stiffness

moment on foundation $(\mathrm{Nm})$

maximum moment applied $(\mathrm{Nm})$

minimum moment applied $(\mathrm{Nm})$

static moment capacity $(\mathrm{Nm})$

number of cycles

atmospheric pressure $(\mathrm{kPa})$

foundation rotation coefficient

\author{
caisson wall thickness (m) \\ vertical load on foundation $(\mathrm{N})$ \\ vertical settlement $(\mathrm{m})$ \\ caisson skirt length (m) \\ rotation coefficient \\ unit weight of soil $\left(\mathrm{N} / \mathrm{m}^{3}\right)$ \\ observed rotation ( $\mathrm{rad})$ \\ static unit rotation ( $\mathrm{rad})$ \\ regime loading level \\ regime loading directionality \\ friction angle $\left({ }^{\circ}\right)$
}

\section{Introduction}

Most of the current generation of offshore wind turbines are founded on so-called monopile foundations; these are essentially large-diameter piles that are hammered into the seabed. Monopile foundations, by their very nature, are expensive owing to the pile-driving equipment and support vessels needed. In addition, the noise generated by piling requires environmental mitigation. The cost of such foundation arrangements alone makes up around $20 \%$ of an offshore 
Centrifuge study on the cyclic performance of caissons in sand Cox, O'Loughlin, Cassidy et al. wind project (Carter, 2007; DTI, 2001, 2007; Kühn et al., 1998; Larsen et al., 2005). An alternative foundation for offshore wind turbines is the suction caisson, which is a large-diameter steel bucket foundation that is embedded in the local seabed using suction (see Figure 1). Suction caissons have been widely used by the offshore oil and gas industry, particularly for anchoring large floating facilities (Andersen et al., 2005), but also as footings for jacket and jack-up structures.

Suction caissons have only seen use in a few dynamically sensitive structures, such as wind turbines (Frederikshavn wind turbine; Liingaard (2006)) and met masts (Horns Rev 2 offshore wind farm; LeBlanc (2009a)). Offshore wind turbines have stringent serviceability limit states, defining the total rotation and modal frequencies of the structure. This is of particular concern as the mechanical components exhibit a reduced design life when subjected to misalignment or dynamic loading. Accordingly (as in the case of the Thornton Bank wind park) the total structural rotation is limited to $0 \cdot 25^{\circ}$ (Peire et al., 2009) and the modal frequencies are required to differ by $10 \%$ to that

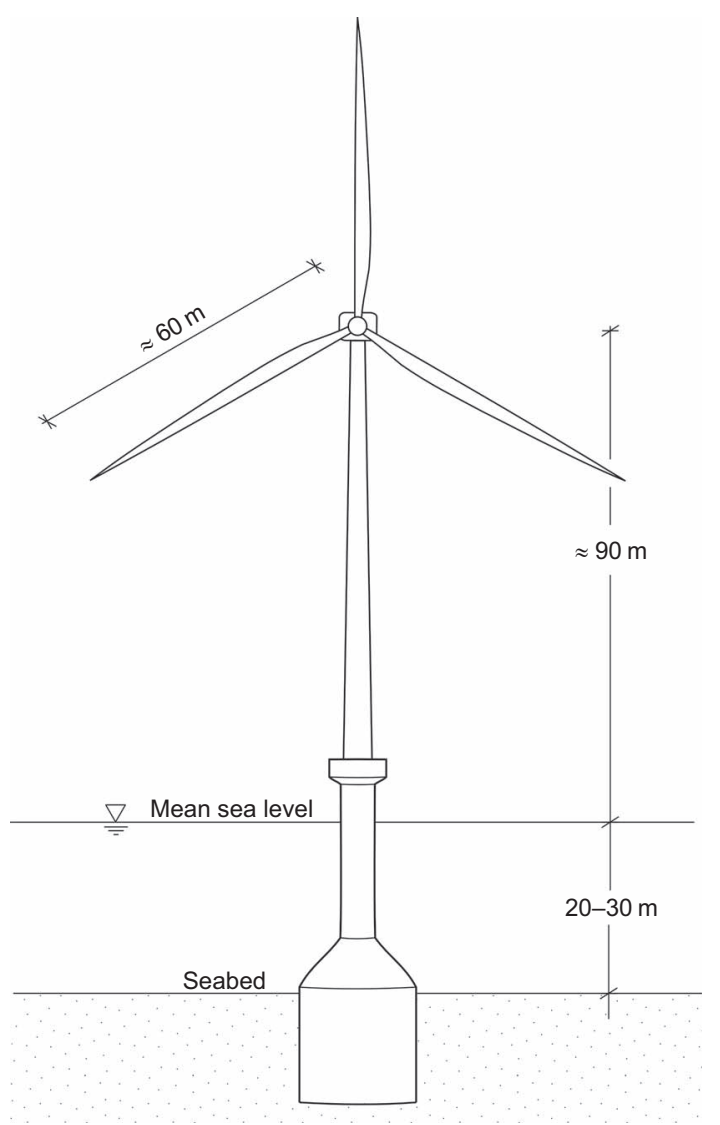

Figure 1. Arrangement of a typical $5 \mathrm{MW}$ offshore wind turbine founded on a single suction caisson of the periodic wind, wave, current and vortex loads (Det Norske Veritas, 2002). An example of the dynamic forces that an offshore turbine will be subjected to and the design solutions, where the first modal frequency of the turbine can be safely designed, is illustrated in Figure 2. These solutions are often referred to as soft-stiff and stiff-stiff zones; these describe the regions between the $1 \mathrm{P}$ and $3 \mathrm{P}$ frequencies and the region above the $3 \mathrm{P}$ frequency, respectively, where $\mathrm{P}$ is the rotational frequency of the turbine. From a design perspective, the risk is that during long-term cyclic loading the foundation stiffness may change, causing the natural frequency of the system to approach either the $1 \mathrm{P}$ or $3 \mathrm{P}$ frequencies, producing resonance.

Offshore wind turbines are very recent structures, with the first experimental offshore turbines being constructed in 1991 and large-scale projects being developed from the early 2000s (Zaaijer, 2009). As a result there are scant operational data concerning the long-term behaviour of an offshore turbine system. Accordingly a significant amount of recent research has considered the performance of wind turbine foundations (particularly monopiles) when subjected to long-term cyclic loading (Bhattacharya et al., 2012; LeBlanc et al., 2010a). Much of the work on suction caissons has focused on scaled tests, modelling the monotonic caisson response (Feld, 2001; Houlsby et al., 2005; Villalobos, 2006), and the behaviour of a caisson subjected to a series of cyclic loading regimes (Byrne, 2000; Villalobos, 2006; Zhu et al., 2013). Such tests have been conducted under $1 \mathrm{~g}$ conditions and require verification at stress levels more typical in the prototype. To address this, some limited tests have been conducted in saturated sands at a prototype scale (Kelly et al., 2006; Liingaard, 2006) and in a centrifuge (Lu et al., 2007; Senders, 2008; Zhang et al., 2007). These were, however, only conducted for a limited number of cycles and were primarily concerned with the accumulation of pore water pressure under extreme loading situations. Despite the quality and rigour of such investigations, there is still a limited amount of knowledge surrounding the long-term applicability of caisson foundations at prototype scale.

The contribution of this paper is a database of centrifuge results from tests conducted in very dense dry sand that focused on the accumulation of rotation and the stiffness changes with increasing number of cycles.

\section{Centrifuge test programme}

All tests in this programme were conducted in a geotechnical centrifuge to ensure that the stress-strain behaviour (and hence geotechnical behaviour) in the model were the same as in the equivalent prototype (Gaudin et al., 2010). The tests in this investigation were conducted at $200 \mathrm{~g}$ using the beam centrifuge facility at the Centre for Offshore Foundation Systems at The University of Western Australia. A description of the centrifuge and its capabilities is detailed elsewhere (Randolph et al., 1991). 
International Journal of Physical Modelling in Geotechnics Volume 14 Issue 4
Centrifuge study on the cyclic performance of caissons in sand Cox, O'Loughlin, Cassidy et al.

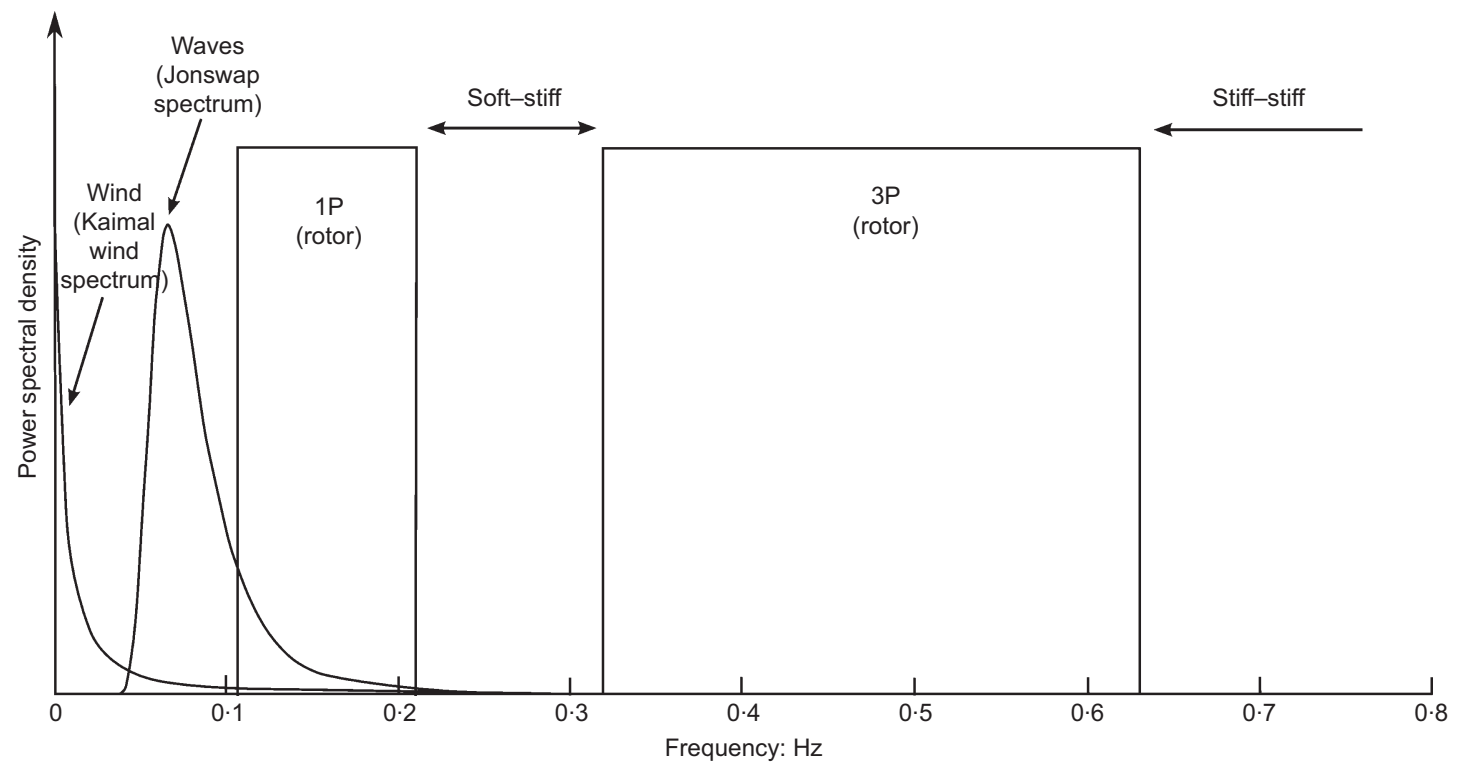

Figure 2. Typical loading frequencies and dynamically sensitive regions of a NREL $5 \mathrm{MW}$ turbine structure (after Bhattacharya et al.; 2012)

To ensure that the loads subjected to the model caissons are representative of the forces expected at full scale, a number of prototype cases were analysed. The behaviour of these full-scale structures was then rationalised in the form of non-dimensional groups characterising the key aspects of the systems. The nondimensional groups considered in this investigation, shown in Table 1, describe the relative flexibility of the model caissons (group 1), the aspect ratio (group 2), the soil stress (groups 3-5) and the strain properties (group 6) of the foundation as a whole. The derivation and explanation of the groups has been covered before and can be found in Doherty et al. (2005), Cox and Bhattacharya (2012) and Foglia and Ibsen (2013).

Three dynamically sensitive offshore structures have been founded on suction caissons: the $3 \mathrm{MW}$ Frederikshavn quasioffshore wind turbine (Liingaard, 2006), the 5 MW Wilhelmshaven offshore wind turbine (LeBlanc, 2009a) and the Horns Rev 2 met mast (LeBlanc, 2009b). Targeted nondimensional scaling values have been determined from these structures and are detailed in Table 1, with full notation provided at the beginning of the paper. A description of the material properties, geometry and the load reference point utilised in the non-dimensional groups is provided in Figure 3.

It was also necessary to scale the corresponding caisson response to extract the relevant data; this was achieved using the non-dimensional groupings suggested by Kelly et al. (2006) (and presented in Table 2), which permits comparisons between the results of this study with those conducted at different scales.

In this investigation two model caissons, herein referred to as caisson $\mathrm{C} 2$ and caisson $\mathrm{C} 3$, were considered to reflect the prototype structures described in Table 1 . The aspect ratios (group 2) of the two caissons were $Z / D=1$ and 0.5 for caissons $\mathrm{C} 2$ and $\mathrm{C} 3$ respectively. Each model was designed such that the caisson flexibility (group 1) was 9.35. This was achieved by choosing a diameter of $80 \mathrm{~mm}$ and manufacturing the caissons from aluminium (Young's modulus, $E_{\mathrm{s}}=$ $70 \mathrm{MPa}$ ), with a wall thickness $t=1.4 \mathrm{~mm}$. Assuming a shear modulus, $G_{\mathrm{r}}=130 \mathrm{MPa}$ (Hardin and Drnevich, 1972) and an average effective unit weight, $\gamma^{\prime}=17 \cdot 4 \mathrm{kN} / \mathrm{m}^{3}$, a strain multiplier (group 6) of 476 was achieved, slightly higher than but comparable to the Frederikshavn and Horn Rev 2 caissons. The dimensionless vertical capacity (group 3) was within the quoted offshore range in Table 1 , with values of 0.74 for the $\mathrm{C} 2$ caisson and 0.69 for the $\mathrm{C} 3$ caisson. The two model caissons are shown in Figure 4 and measurement details for each caisson are detailed in Table 3.

Tests were conducted in a centrifuge strong box with internal dimensions $650 \times 390 \times 300 \mathrm{~mm}$ (length $\times$ width $\times$ depth) filled with very dense sample of 'super fine silica sand' (with $e_{\max }=0.747, e_{\min }=0.449, D_{50}=0.15 \mathrm{~mm}$ and $\varphi_{\mathrm{cv}}=31^{\circ}($ Liu and Lehane, 2012; O'Loughlin and Lehane, 2003)), and as such the particle size to foundation diameter ratio was greater than 


\begin{tabular}{|c|c|c|c|c|c|c|}
\hline Group & No. & Description & Frederikshavn & Wilhelmshaven & $\begin{array}{c}\text { Horns Rev } 2 \text { Met } \\
\text { mast }\end{array}$ & Test models \\
\hline$\frac{E_{\mathrm{s}} t}{G_{\mathrm{r}} D}$ & 1 & Caisson flexibility & $10 \cdot 10$ & $7 \cdot 89$ & $6 \cdot 73^{\mathrm{a}}$ & $9 \cdot 20$ \\
\hline$\frac{Z}{D}$ & 2 & Caisson aspect ratio & $0 \cdot 50$ & 1.00 & $0 \cdot 50$ & $0 \cdot 50 / 1 \cdot 00$ \\
\hline$\frac{V}{\gamma^{\prime} D^{3}}$ & 3 & Vertical caisson capacity & 0.48 & 0.43 & 0.99 & $0 \cdot 69 / 0 \cdot 76$ \\
\hline$\frac{H}{\gamma^{\prime} D^{3}}$ & 4 & Horizontal caisson capacity & 0.05 & 0.05 & 0.06 & Varies \\
\hline$\frac{M}{\gamma^{\prime} D^{4}}$ & 5 & Moment caisson capacity & $0 \cdot 39$ & $0 \cdot 28$ & 0.04 & Varies \\
\hline$\frac{G_{r}}{\gamma^{\prime} D}$ & 6 & $\begin{array}{l}\text { Strain multiplier (considers } \\
\text { relative stress-strain behaviour) }\end{array}$ & $436 \cdot 7$ & $392 \cdot 9$ & $436 \cdot 7$ & $475 \cdot 9$ \\
\hline
\end{tabular}

aThickness calculated from DNV guidelines (DNV-RP-C202 Det Norske Veritas (2010))

Table 1. Prototype non-dimensional groupings (Det Norske Veritas, 2010)

60 (Hoadley et al., 1981). Each sample was prepared in an identical manner using the sand pluviation technique to give final sample heights of approximately $200 \mathrm{~mm}$. Global measurements of the sample volume and mass gave unit weights in the range $17 \cdot 4-17 \cdot 5 \mathrm{kN} / \mathrm{m}^{3}\left(D_{\mathrm{r}}=86 \cdot 5 \pm 2 \cdot 5 \%\right)$ at $1 \mathrm{~g}$. The available plan testing area in the strongbox permitted three tests to be conducted in each sample, allowing a minimum edge-to-edge clearance of two diameters between test locations. Based on the radial consolidation solution proposed by Randolph and Wroth (1979), it was found that for a range of typical loading frequencies and permeabilities, a prototype foundation would predominantly behave in a drained manner, with partially drained behaviour seen under low-permeability

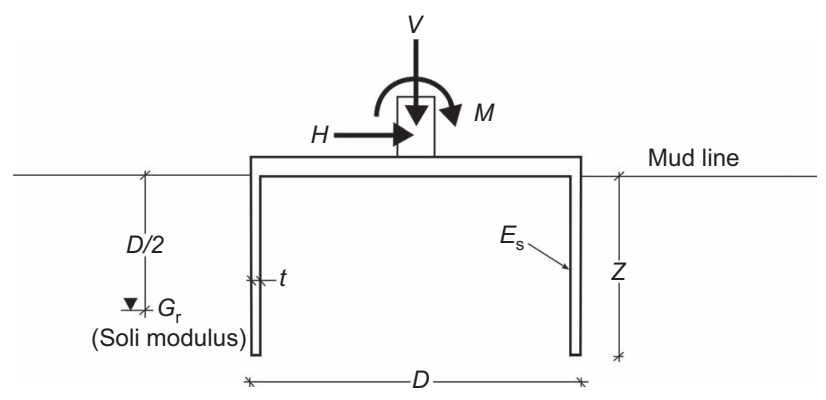

Figure 3. Notation and load reference point utilised in the nondimensional groupings following the definitions of Doherty et al. (2005) conditions. Accordingly the sand medium remained dry throughout, replicating a fully drained case.

All caissons in this investigation were installed by jacking using an actuator at $1 \mathrm{~g}$. Installing a foundation at $1 \mathrm{~g}$ causes the sand displaced during jacking to dilate more, increasing the corresponding soil plug heave, in comparison to a prototype case (Tran, 2005). This additional heave will have the effect of reducing the observed caisson capacity; as only the transient behaviour is of interest, the installation was not modelled in this investigation. Load was applied to the caisson system using a pivoted loading arm (Dyson, 1999) at a fixed eccentric height on the model tower to replicate the desired horizontal and moment loads (such that the eccentric height, $h=M / H$ ). Using a combined axial and moment load cell, load control could be achieved in both the horizontal axis (by way of axial load control) and the vertical axis (by way of bending load control). As only a horizontal load was desired, the vertical axis of the actuator was continuously adjusted through a feedback loop to ensure that the moment on the load cell maintained zero and that no change in vertical load was applied to the caisson system.

The system response was measured using the motor encoders on the horizontal and vertical axes of the actuator, two laser potentiometers mounted perpendicular to the axis of forcing and the combined axial and moment load cell. The resulting experimental set-up is illustrated schematically in Figure 5. 
Centrifuge study on the cyclic performance of caissons in sand Cox, O'Loughlin, Cassidy et al.
Angular rotation $[\tilde{\theta}]$

Vertical displacement $[\tilde{W}]$

Unload stiffness in each cycle $[\tilde{k}]$

$$
\begin{gathered}
\theta\left[\frac{P_{\mathrm{a}}}{\gamma^{\prime} D}\right]^{0.5} \\
\frac{\left(\frac{W}{D}\right)\left[\frac{P_{\mathrm{a}}}{\gamma^{\prime} D}\right]^{0.5}}{k} \frac{k}{\left[\left(\gamma^{\prime} P_{\mathrm{a}}\right)^{0.5} D^{3.5}\right]}
\end{gathered}
$$

Table 2. Summary of experimental non-dimensional groups after Kelly et al. (2006)

The following experimental procedures were adopted for each test run.

(a) A centrifuge strong box filled with a sample of very dense silica sand was located on the swinging platform of the centrifuge.

(b) Each sample was spun to $200 \mathrm{~g}$ and a cone penetrometer test (CPT), was conducted to characterise the sample. In this case a $7 \mathrm{~mm}$ diameter cone penetrometer was penetrated at $1 \mathrm{~mm} / \mathrm{s}$.

(c) The sample was spun down to $1 \mathrm{~g}$ and the model caisson was carefully jacked into the sand at a rate of $0.25 \mathrm{~mm} / \mathrm{s}$ at $1 \boldsymbol{g}$ using the actuator, ensuring verticality, until the caisson was fully installed. Subsequently the air vent in the caisson lid was sealed.

(d) The model caisson was then connected to the dual axis actuator by way of the pivoted loading arm.

(e) The centrifuge was then spun up until an acceleration of $200 \mathrm{~g}$ was acting at the mid-depth level of the caisson.

(f) The selected loading regime was then applied to the model and the corresponding response of the system was recorded.

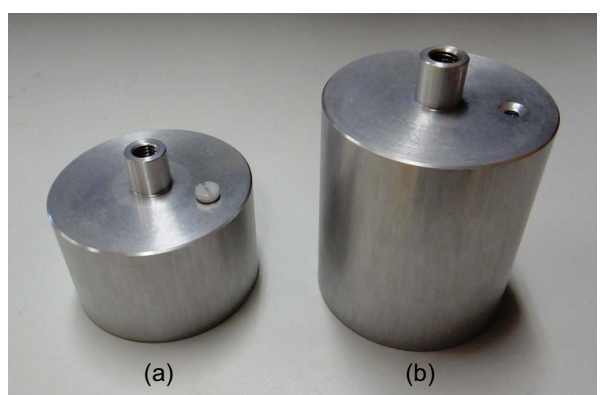

Figure 4. Model caisson used in the centrifuge tests: (a) C3 caisson $(Z / D=0 \cdot 5)$ and $(b) C 2$ caisson $(Z / D=1 \cdot 0)$ (g) At the end of the experiment the centrifuge was spun down to $1 \boldsymbol{g}$ and steps $(c)-(f)$ were repeated for further tests at different sites in the strong box.

In this investigation two separate loading regimes were applied to the model system. Each of these regimes was designed to test the changing serviceability state of the caisson system. These loading regimes were as outlined below.

(a) Push-over tests [P]: these tests allowed the quasi-static stiffness of the caisson to be assessed by steadily displacing the model at an eccentric height and measuring the resultant load.

(b) Cyclic tests [C]: the loading in this regime was intended to closely match what would be applied to an offshore wind turbine (a large static wind force augmented by a varying wind and wave load). In these experiments the varying component was assumed to be a sine wave. By adjusting the static and varying components of the loading regime, different load situations could be developed. Using the definitions proposed by LeBlanc et al. (2010b) the load orientation and magnitude can be defined as

1. $\xi_{\mathrm{b}}=\frac{\mathrm{M}_{\max }}{\mathrm{M}_{\mathrm{R}}}$

2. $\xi_{\mathrm{c}}=\frac{\mathrm{M}_{\min }}{\mathrm{M}_{\max }}$

where $\xi_{\mathrm{b}}$ specifies the load level as a ratio of the maximum moment and the static moment capacity, and $\xi_{\mathrm{c}}$ represents the relative directionality (where $\xi_{\mathrm{c}}=-1$ represents a symmetrical two-way loading and $\xi_{\mathrm{c}}=0$ represents a purely one-way regime); this is illustrated in Figure 6.

Each experiment was subsequently identified with a unique label describing the test that was conducted. This label denotes 


\begin{tabular}{llcccc} 
ID & Description & Diameter, $D: \mathrm{mm}$ & Skirt length, $Z$ : $\mathrm{mm}$ & Thickness, $t: \mathrm{mm}$ & Mass at $1 \boldsymbol{g}: \mathrm{kg}$ \\
\hline C2 & 5MW model, 1:200 & $80 \cdot 0$ & $80 \cdot 0$ & 1.4 & 0.68 \\
C3 & 5MW model, 1:200 & $80 \cdot 0$ & $40 \cdot 0$ & 1.4 & 0.65
\end{tabular}

Table 3. Details of centrifuge model caissons

the size of caisson used, the adopted loading regime and the test number. For example, the second test under a cyclic loading using a $\mathrm{C} 3$ caisson would be labelled as $\mathrm{C} 3-\mathrm{C}-2$.

\section{Analysis}

From the data recorded during each test it was possible to determine a number of basic responses of the system. Characteristics such as the instantaneous point of rotation, the moment load, the vertical settlement, the change and accumulation of rotation of the caisson system were easily calculated.

Utilising the moment rotation plots it was possible to calculate the rotational stiffness of the foundation throughout the experiment. This was achieved by identifying the maximum and minimum loads and the corresponding rotations within each loading cycle. By considering the difference between the moment and rotation, the unloading rotational stiffness could

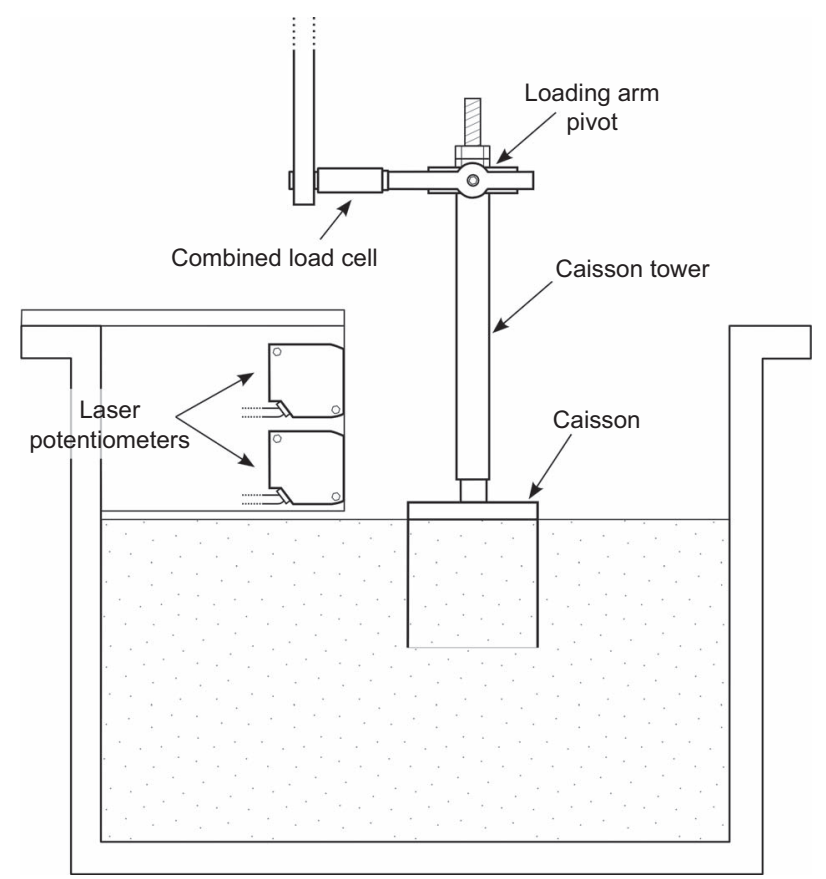

Figure 5. Cross-section schematic diagram of the test layout be calculated in a similar manner to LeBlanc et al. (2010a) and Zhu et al. (2013). This methodology is illustrated in Figure 7.

\section{Results}

The experimental programme considered here encompasses two push-over tests and thirteen cyclic tests using two different caissons. A summary of the tests conducted in this investigation is provided in Table 4 .

\subsection{Cone penetration tests (CPTs)}

Within each sample two CPTs were conducted to characterise the sample. Utilising these CPT records the repeatability of the sample preparation method could be assessed. From the CPT data it was noted that there was reasonable consistency between the sand samples; the variation between samples can be attributed to minor inhomogeneity. The cone resistance with depth for all these tests is shown in Figure 8.

\subsection{Installation}

Each caisson was installed in the manner described previously. Full installation was defined as the point at which the caisson soffit contacted the soil plug, identified by a rapid increase in the installation load. These installation records were consistent with an embedment of $88-90 \%$ of the total skirt length. A series of typical installation records is given in Figure 9.

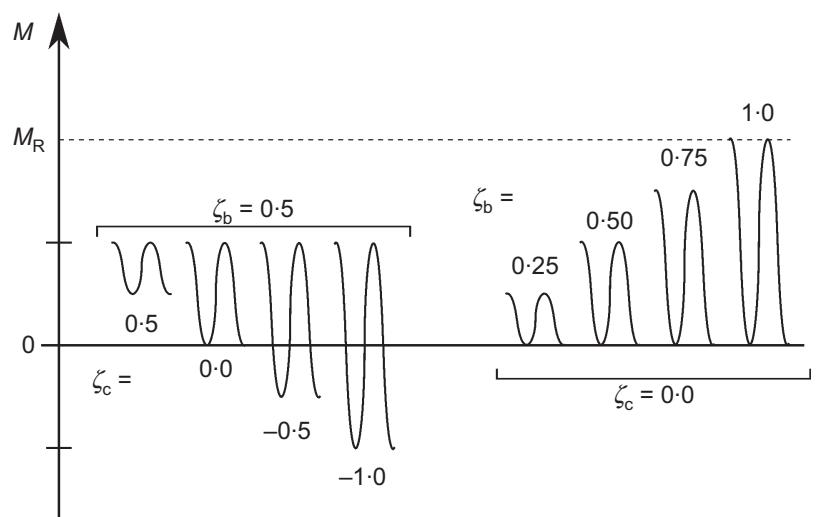

Figure 6. Definition of cyclic parameters (after Zhu et al.; 2013) 
Centrifuge study on the cyclic performance of caissons in sand Cox, O'Loughlin, Cassidy et al.

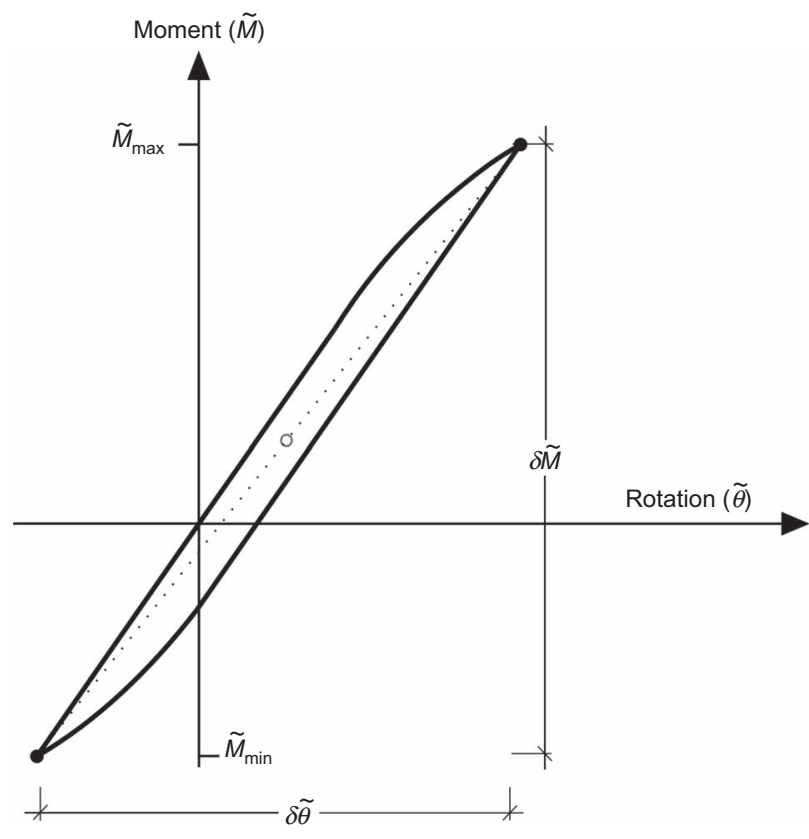

Figure 7. Unloading stiffness definition for a single loading cycle

\subsection{Pushover}

A pushover test $(M / H D=3 \cdot 3)$ was conducted for both caisson geometries by displacing the caisson tower at an eccentric height at a constant rate of $0.05 \mathrm{~mm} / \mathrm{s}$. The load measured during the pushover test allowed calculation of the static unit rotation $\left(\theta_{\mathrm{s}}\right)$ to be made; this is the structural rotation observed

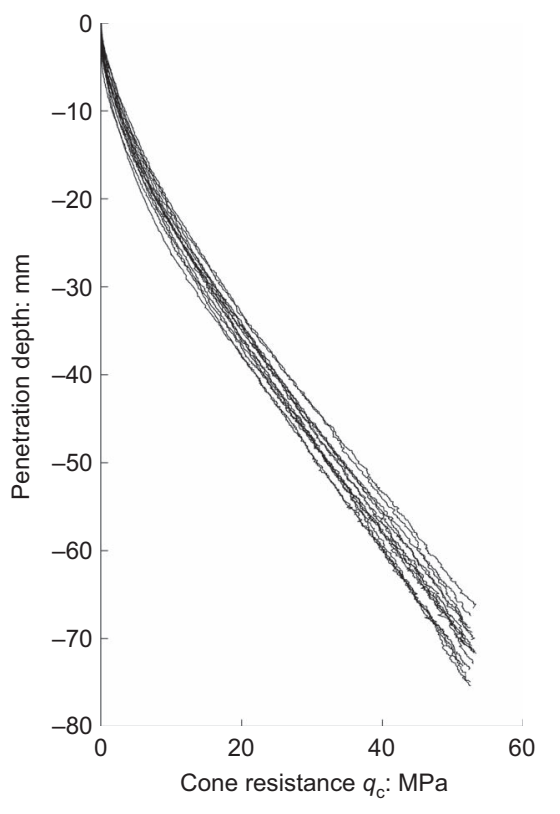

Figure 8. CPT data for all sand samples used in this investigation

when the maximum load in a cyclic series is applied to the system under monotonic conditions. Utilising the relationships described in Table 1 and Table 2 it was possible to nondimensionalise the results, thus presenting the behaviour in terms of the load level $\left[M / \gamma^{\prime} D^{4}\right]$ and rotational strain $\left[\theta /\left(P_{\mathrm{a}} /\right.\right.$ $\left.\gamma^{\prime} D\right)^{0.5}$. These results are shown in Figure 10 alongside the yield load calculated in the same manner as Zhu et al. (2013).

\begin{tabular}{|c|c|c|c|c|c|c|}
\hline Test ID & $\begin{array}{l}\text { Percentage } \\
\text { installed: \% }\end{array}$ & Number of cycles: $N$ & $H / \gamma^{\prime} D^{3}$ & $\mathrm{M} / \gamma^{\prime} D^{4}$ & $\xi_{\mathrm{b}}$ & $\xi_{c}$ \\
\hline C3-P-1 & $90 \cdot 2$ & - & - & - & - & - \\
\hline C3-C-1 & $89 \cdot 1$ & 71 & 0.04 & $0 \cdot 12$ & 0.40 & 0.02 \\
\hline C $3-C-2$ & $88 \cdot 8$ & 1877 & 0.06 & $0 \cdot 18$ & 0.60 & $0 \cdot 34$ \\
\hline C $3-C-5$ & $89 \cdot 3$ & 690 & 0.08 & $0 \cdot 24$ & $0 \cdot 80$ & 0.00 \\
\hline C $3-C-6$ & $90 \cdot 1$ & 9329 & 0.02 & 0.06 & $0 \cdot 20$ & -0.89 \\
\hline C $3-C-7$ & $89 \cdot 7$ & 2209 & 0.04 & $0 \cdot 12$ & 0.40 & -0.99 \\
\hline C2-P-3 & $88 \cdot 3$ & - & - & - & - & - \\
\hline$C 2-C-1$ & $89 \cdot 0$ & 1555 & $0 \cdot 16$ & 0.51 & $0 \cdot 54$ & 0.01 \\
\hline$C 2-C-2$ & $90 \cdot 2$ & 1587 & $0 \cdot 16$ & 0.51 & $0 \cdot 54$ & 0.52 \\
\hline$C 2-C-3$ & $89 \cdot 2$ & 2367 & $0 \cdot 24$ & 0.77 & $0 \cdot 81$ & $-0 \cdot 32$ \\
\hline$C 2-C-4$ & $88 \cdot 9$ & 2597 & $0 \cdot 24$ & 0.75 & $0 \cdot 79$ & $0 \cdot 34$ \\
\hline$C 2-C-5$ & $87 \cdot 8$ & 2187 & $0 \cdot 24$ & $0 \cdot 76$ & $0 \cdot 80$ & 0.03 \\
\hline$C 2-C-6$ & $89 \cdot 6$ & 1962 & 0.08 & $0 \cdot 25$ & $0 \cdot 26$ & -0.97 \\
\hline$C 2-C-7$ & $90 \cdot 3$ & 12121 & $0 \cdot 16$ & 0.52 & 0.55 & -0.99 \\
\hline$C 2-C-8$ & $88 \cdot 9$ & 6985 & $0 \cdot 24$ & 0.73 & $0 \cdot 77$ & -0.88 \\
\hline
\end{tabular}

Table 4. Centrifuge tests parameters 
Centrifuge study on the cyclic performance of caissons in sand Cox, O'Loughlin, Cassidy et al.

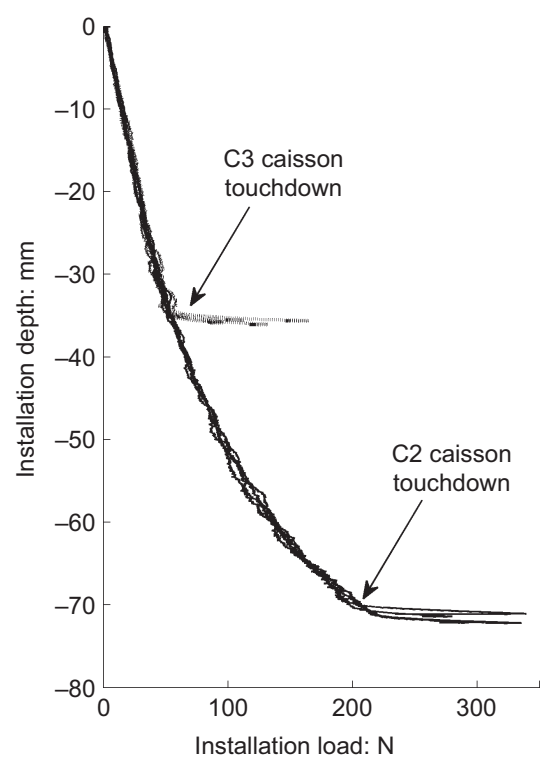

Figure 9. Caisson installation records conducted at $\mathbf{1 g}$

It is evident from Figure 10 that the increased caisson skirt length has a significant effect on the moment capacity of the system. Furthermore the failure modes are different: caisson C3 displays a residual strength similar to that of the peak load, whereas caisson $\mathrm{C} 2$ continues to gain strength. This observed ductility in caisson $\mathrm{C} 2$ must be a direct result of changes in the failure mechanism owing to the increased embedment.

Furthermore it is possible to evaluate the change in nondimensional stiffness with rotation level, considering secant values from the pushover data in Figure 10; this degradation is plotted in Figure 11. Figure 11 shows a higher stiffness for caisson C2 (also evident from the steeper slope of the pushover data in Figure 10), and is to be expected given the longer skirt length. The non-dimensional stiffness remains tolerably constant over the linear portion of the pushover tests (up to approximately $\theta=10^{-2}$ ), before degrading with increasing rotation, qualitatively similar to plots of shear modulus against strain level (Hardin and Drnevich, 1972).

\subsection{Unloading stiffness}

Under cyclic loading the caisson stiffness was assessed as previously described, and the resulting data were nondimensionalised using the groups proposed by Kelly et al. (2006) and plotted against cycles number in Figure 12. Anomalous behaviour was noted in the first few cycles of test C2-C-4 data set as the caisson was bedding in, and accordingly this behaviour has been omitted from all analyses. It should be noted that during the $\mathrm{C} 2-\mathrm{C}-8$ test series, there was a temporary issue with the data acquisition system leading to a gap in the data.

It is evident from Figure 12 that the evolution of stiffness with increasing cycle number is quite erratic (as also observed by LeBlanc et al. (2010a) during cyclic loading of monopiles); this is not unexpected as the displacement amplitudes considered are very small. However, for tests involving long-term cyclic loading (i.e. $N>1000$ ) an increase or maintenance of the rotational stiffness was observed. Following similar work by Sawicki and Swidzinski (1989) on the stiffness of sand under triaxial loading conditions and by $\mathrm{Li}$ et al. (2010) on the stiffness of a model pile system, a logarithmic relationship was used to express the changing stiffness of the foundation. Utilising the following relationship the non-dimensional change in stiffness can be described with increasing number of loading cycles

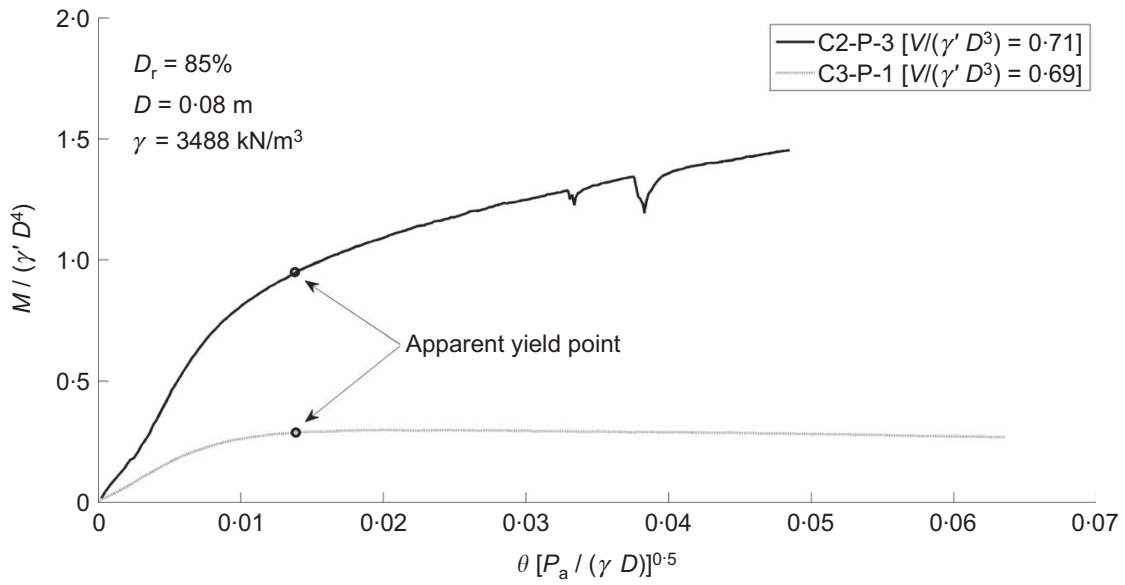

Figure 10 Non-dimensional pushover results 


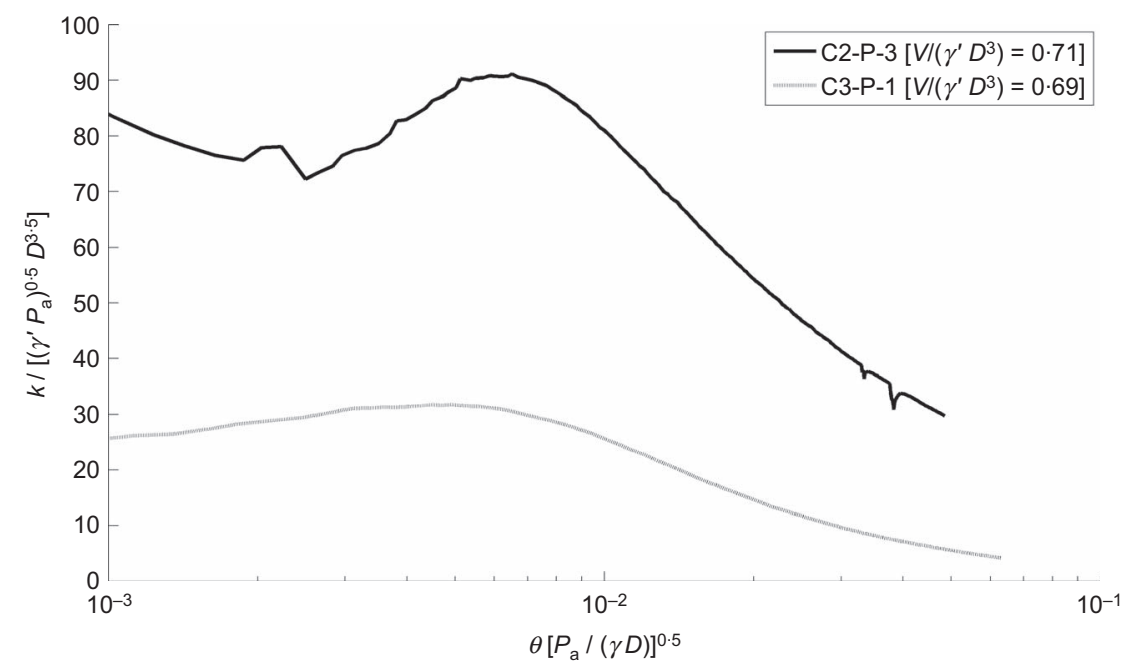

Figure 11. Calculated non-dimensional stiffness with rotation level

\section{3. $\tilde{k}=K_{0}+A_{k} \ln (N)$}

where $\tilde{k}$ is the instantaneous non-dimensional foundation stiffness, $K_{0}$ is the characteristic non-dimensional foundation stiffness and $A_{k}$ is the stiffness change parameter. Despite the erratic evolution of the stiffness, Equation 3 was mapped to the data such that the long-term stiffness was adequately described (indicated by the dotted lines on Figure 12); this was achieved using a constant stiffness parameter $\left(A_{k}\right)$ of 1.52 and values of $K_{0}$ which varied for each test as summarised in Table 5.

Figure 12 and Table 5 show that caisson C2 is approximately twice as stiff as caisson $\mathrm{C} 3$, which is also evident from the stiffness derived from the pushover data and shown on Figure 11, and is attributed to the greater skirt depth. The characteristic stiffness $K_{0}$ appears to be fairly consistent between tests, the load level $\left(\xi_{\mathrm{b}}\right)$ and load directionality $\left(\xi_{\mathrm{c}}\right)$ appear to have an effect on the resulting behaviour; however, it is minimal. This is not unexpected as all tests are conducted within or close to the elastic range of the soil. A comparison of Figure 12 with Figure 11 suggests that a reasonable approximation of the characteristic stiffness $K_{0}$ can be obtained from the pushover test (considering rotation levels).

The stiffness change parameter, $A_{k}=1 \cdot 52$, as determined for the suction caisson data reported here, is much lower than $A_{k}$ $=8$ as observed by LeBlanc et al. (2010a) for model tests on monopiles. This behaviour can be attributed to the tests in this instance being conducted at $200 \mathrm{~g}$ with a high relative density ( $\sim 85 \%)$, compared to the test of LeBlanc et al. (2010a) conducted at $1 \mathrm{~g}$ in a loose sand sample $(\sim 35 \%)$. It is not unreasonable to see a lower rate of stiffness change in this instance as there is a lower potential for the sand to densify.

\subsection{Rotation of the caisson}

For each loading condition the accumulation or retention of rotation was assessed. This was achieved by considering the mean rotation observed during a single loading cycle. In all cases an initial rapid accumulation of rotation was observed which slowed down with additional loading cycles (and increased foundation stiffness). The resulting absolute change in rotation could then be normalised with respect to the static unit rotation $\left(\theta_{\mathrm{s}}\right)$ and plotted against the number of cycles, as shown in Figure 13.

A number of experimental investigations on monopiles and caissons have developed relationships to describe the accumulation of rotation with number of cycles. A logarithmic relationship has been proposed by Lin and Liao (1999), Verdure et al. (2003) and $\mathrm{Li}$ et al. (2010) for monopiles whereas a power relationship was proposed by Long and Vanneste (1994), LeBlanc et al. (2010a) and Klinkvort et al. (2010) for monopiles, and by Zhu et al. (2013) for caissons. The data collected in this study were best fitted with a power relationship of the form

4. $\frac{\Delta \theta(N)}{\theta_{s}}=T N^{\alpha}$

As fewer tests were conducted here than in previous investigations (owing to the limited testing window available), the two loading parameters $\xi_{\mathrm{b}}$ and $\xi_{\mathrm{c}}$ (used by LeBlanc et al., 2010a) were combined and considered as a single variable $T$. The data were best fitted using $\alpha=0 \cdot 3$ which is comparable to $\alpha=0 \cdot 31$ reported by LeBlanc et al. (2010a) for monopiles, lower than $\alpha$ $=0.39$ reported by Zhu et al. (2013) but higher than $\alpha=0.18$ proposed by Foglia et al. (2014) also for caissons. The fitting parameters for the tests series are grouped, and the curves corresponding to those fits are plotted in Figure 13 as dotted 


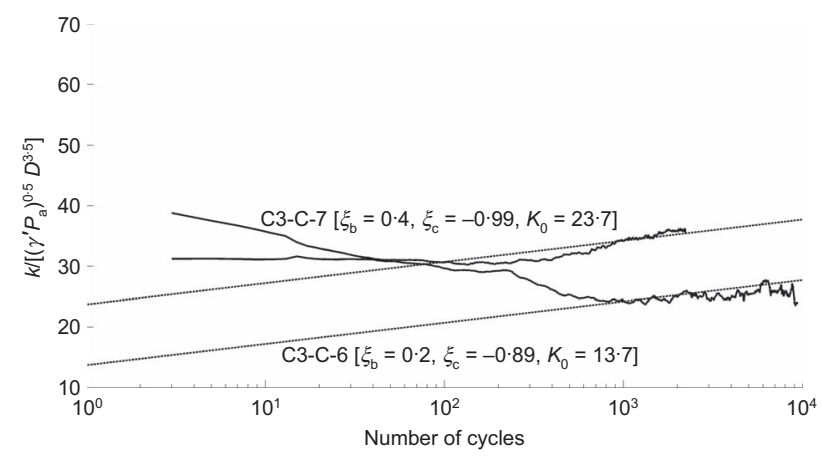

(a)

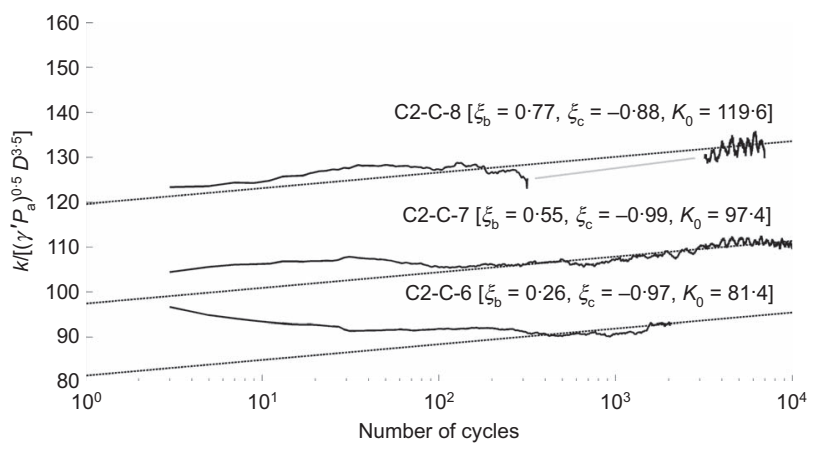

(c)

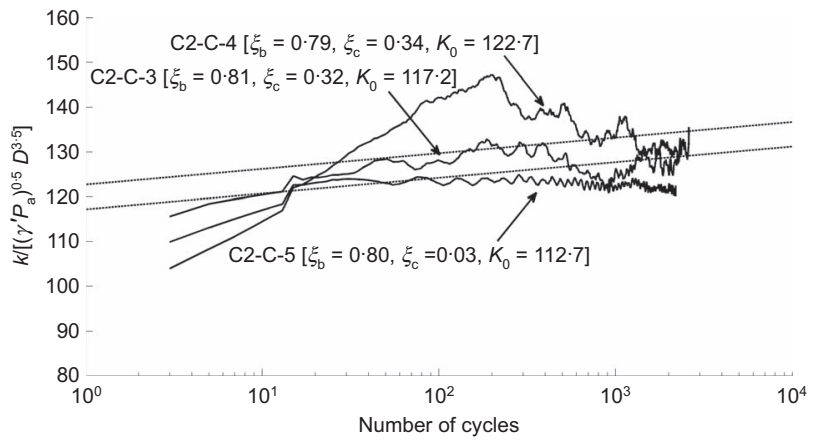

(e)

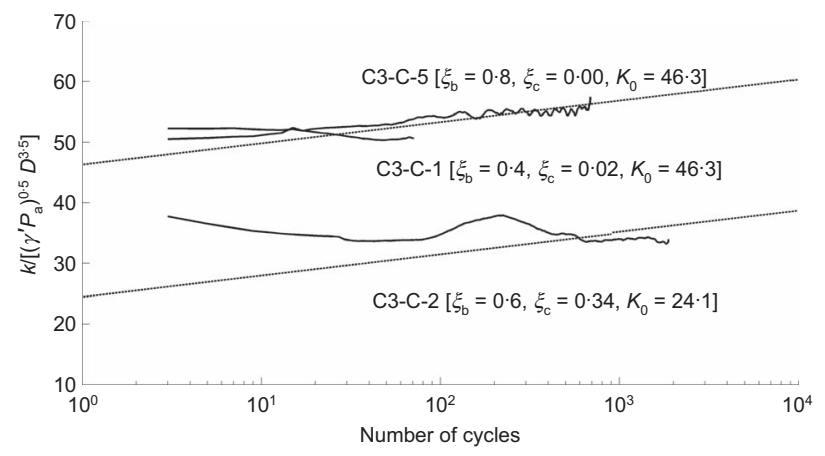

(b)

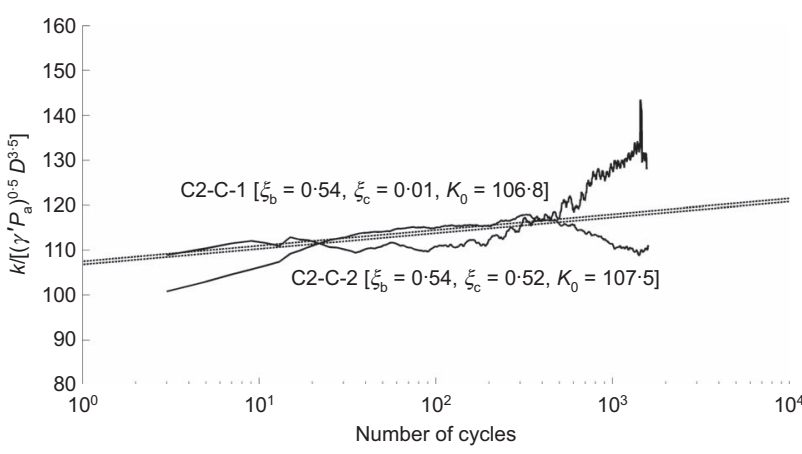

(d)

Figure 12. Non-dimensionalised stiffness with number of loading cycles: (a) C3-C stiffness $\xi_{c}=-1 \cdot 0$; (b) C3-C $\xi_{c}=0 \cdot 0$ : (c) C2-C stiffness $\xi_{\mathrm{c}}=-1 \cdot 0$; (d) $C 2-C \xi_{\mathrm{b}}=0.54$; (e) $C 2-C \xi_{\mathrm{b}}=0.80$

lines. The coefficient $T$ in Equation 4 varied for each test; the fitted parameters are shown in Figure 13 and tabulated in Table 5.

In addition to rotation being observed under one-way loading, rotation was also observed in the two-way loading series $\left(\xi_{\mathrm{b}}=\right.$ $-1)$ against the direction of the first loading cycle, in this case indicated as a negative accumulation of rotation. Intuitively no rotation would be expected in a two-way test, as there is no resultant direction of loading. Similar observations have been made by Rosquoët (2004) and Klinkvort and Hededal (2013) for cyclically loaded monopile foundations in a centrifuge. The accumulation of rotation for all the two-way tests can be seen in Figure 14.

It is believed that the rotation in a two-way test is a result of soil displacements after the first loading cycle. This can be demonstrated by considering the horizontal displacement of the caisson tower (as measured by the laser potentiometers at different heights above the caisson for the first four cycles of loading). The caisson system is vertical when these readings are the same. Instances when this occurs are indicated by the 


\begin{tabular}{|c|c|c|c|c|c|c|}
\hline Test ID & $\xi_{\mathrm{b}}$ & $\xi_{c}$ & $\theta_{\mathrm{s}}: \mathrm{rad}$ & $\Delta \theta: \mathrm{rad}$ & $K_{0}$ & $T$ \\
\hline C3-C-1 & $0 \cdot 40$ & 0.02 & 0.00510 & 0.00410 & $46 \cdot 3$ & 0.097 \\
\hline C $3-C-2$ & 0.60 & $0 \cdot 34$ & 0.00841 & 0.00490 & $24 \cdot 1$ & 0.024 \\
\hline C $3-C-5$ & $0 \cdot 80$ & 0.00 & 0.01330 & 0.00720 & $46 \cdot 3$ & 0.112 \\
\hline C $3-C-6$ & $0 \cdot 20$ & -0.89 & 0.00242 & 0.00640 & $13 \cdot 7$ & 0.044 \\
\hline C $3-C-7$ & 0.40 & -0.99 & 0.00510 & 0.01170 & $23 \cdot 7$ & -0.127 \\
\hline$C 2-C-1$ & $0 \cdot 54$ & 0.01 & 0.01033 & 0.00740 & $106 \cdot 8$ & 0.032 \\
\hline$C 2-C-2$ & 0.54 & 0.52 & 0.01033 & 0.00360 & $107 \cdot 5$ & 0.009 \\
\hline$C 2-C-3$ & $0 \cdot 81$ & $-0 \cdot 32$ & $0 \cdot 01715$ & 0.01400 & $117 \cdot 2$ & 0.057 \\
\hline C2-C-4 & 0.79 & $0 \cdot 34$ & $0 \cdot 01715$ & 0.00580 & $122 \cdot 7$ & 0.020 \\
\hline$C 2-C-5$ & $0 \cdot 80$ & 0.03 & $0 \cdot 01715$ & $0 \cdot 01040$ & $122 \cdot 3$ & 0.039 \\
\hline$C 2-C-6$ & $0 \cdot 26$ & -0.97 & 0.00475 & 0.00930 & $81 \cdot 4$ & -0.122 \\
\hline C2-C-7 & 0.55 & -0.99 & 0.01033 & 0.01570 & $97 \cdot 4$ & -0.037 \\
\hline C2-C-8 & 0.77 & -0.88 & 0.01715 & 0.02180 & $119 \cdot 6$ & -0.021 \\
\hline
\end{tabular}

Table 5. Summary of centrifuge test results

circles for test C2-C-8 as shown in Figure 15(a), alongside that of a typical one-way response for the $\mathrm{C} 2-\mathrm{C}-3$ test as shown in Figure 15(b). It is evident from Figure 15(a) that the lateral displacement between vertical positions reduces with increasing number of cycles, indicating an increase in horizontal caisson stiffness. The majority of this stiffening (displacement change) appears to happen in the direction of the first loading cycle, indicated by the shifting verticality point. This behaviour has the effect of producing an accumulation of structural rotation away from the direction, of the initial loading cycle.

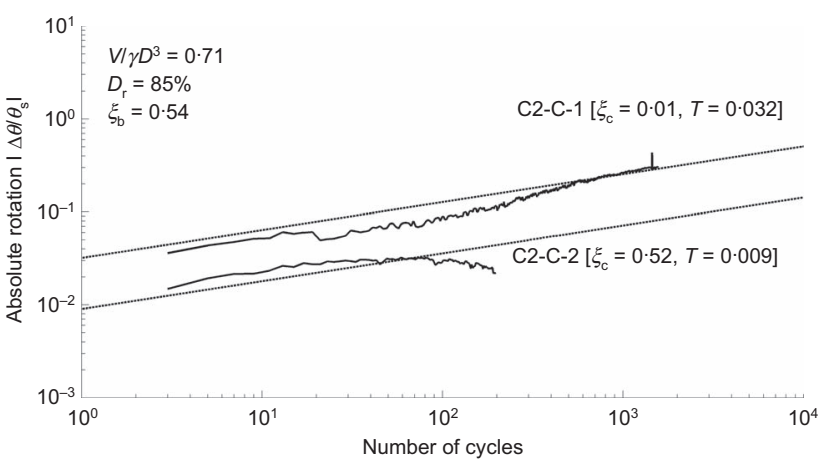

(b)

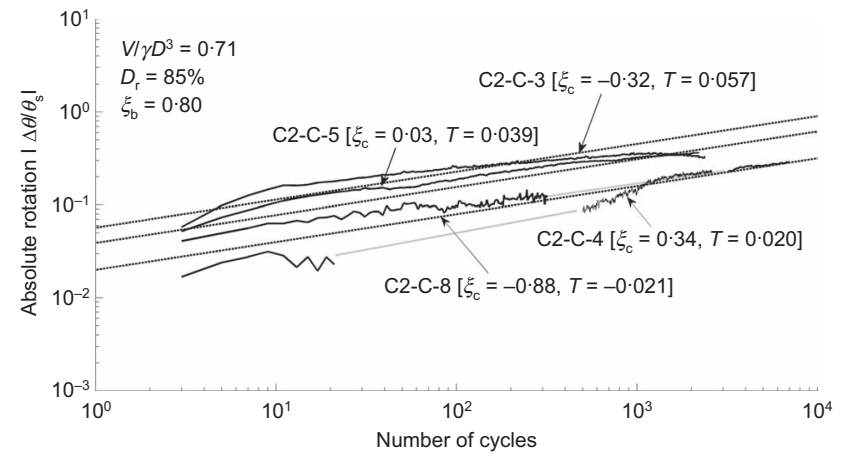

(c)

Figure 13. Non-dimensionalised accumulation of rotation: (a) C3-C $\xi_{\mathrm{c}}=0 ;(\mathrm{b}) \mathrm{C} 2-\mathrm{C} \xi_{\mathrm{b}}=0.54$; (c) C2-C $\xi_{\mathrm{b}}=0.80$ 


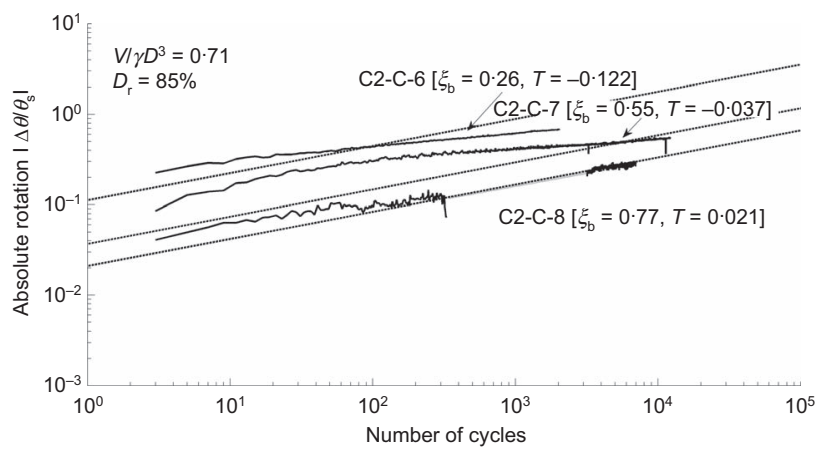

(a)

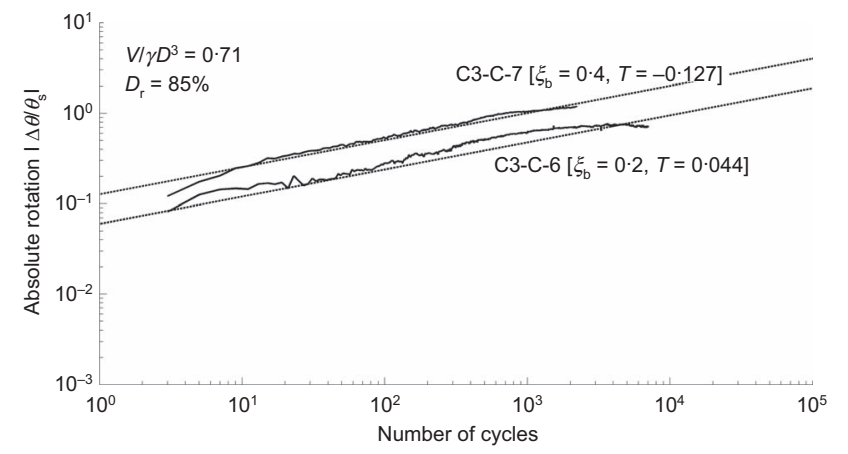

(b)

Figure 14. Two-way accumulation of rotation: (a) C2 caisson;

(b) C3 caisson

Assuming that initially the sand was relatively undisturbed, during the first loading cycle the lateral sand stress will increase in the compression zone and reduce in the tensile zone. This causes a differential sand density either side of the caisson, shown schematically in Figure 16. The initial compression zone will exhibit a greater potential for densification compared to the tensile zone, which will lead to an accumulation of rotation away from the direction of the first loading cycle.

It was subsequently possible to map how each loading regime affected the accumulation of rotation. These results are presented alongside those of Zhu et al. (2013) and Foglia et al. (2014) in Figure 17. The results show similar behaviour to that observed

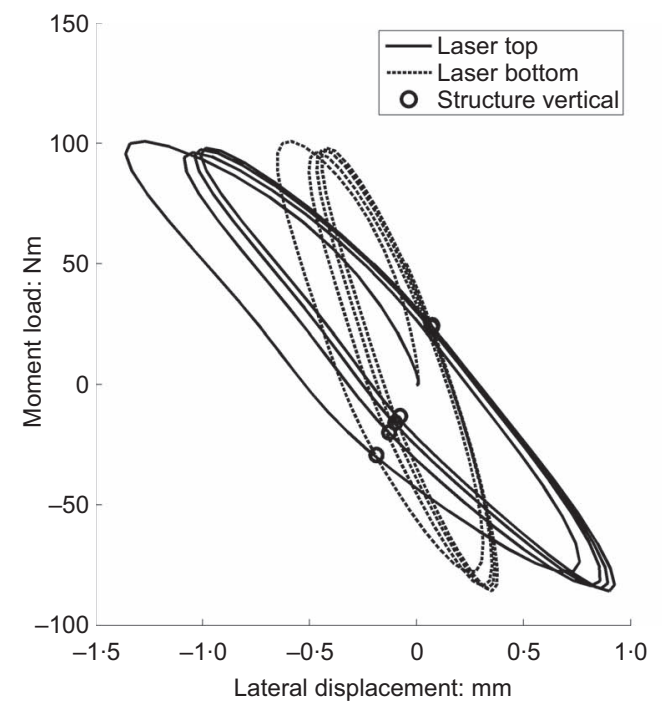

(a) previously in $1 \mathrm{~g}$ experiments, such as large loading regimes causing a greater accumulation of rotation (as illustrated by comparing $\mathrm{C} 3-\mathrm{C}-1$ to $\mathrm{C} 3-\mathrm{C}-5$ and $\mathrm{C} 2-\mathrm{C}-1$ to $\mathrm{C} 2-\mathrm{C}-5$ ) and a loading directionality somewhere between one-way and two-way producing the greatest aggregated rotation (shown by test C2-C-3).

\subsection{Settlement}

Under the application of a cyclic load the caisson system was observed to settle. Although no data fitting was applied to these results, a number of factors affected the magnitude of the observed settlement. In general, caissons subjected to a greater maximum load $\left(\xi_{\mathrm{b}}\right)$ were observed to settle more, as shown in Figure 18(a). In addition, the more two-way the loading

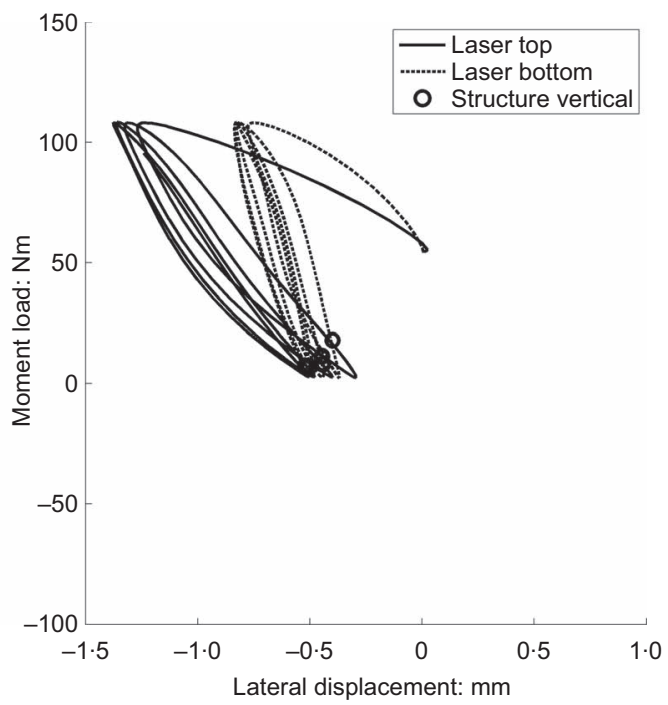

(b)

Figure 15. Individual displacement reading from the two laser potentiometers: (a) C2-C-8; (b) C2-C-3 


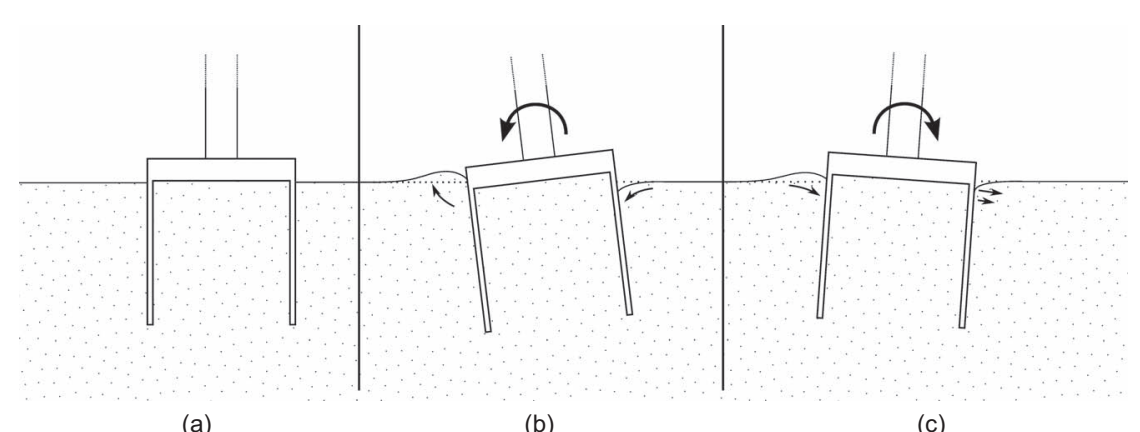

(a)

(b)

(c)

Figure 16. Assumption of local sand movements from observations: (a) undisturbed sand level; (b) sand is displaced in the compression zone and slumps in the tensile zone; (c) the previously displaced sand is allowed to settle and the subducted material is displaced

regime became (i.e. as $\xi_{\mathrm{c}}$ approaches $-1 \cdot 0$ ), the greater the settlements that were observed, as illustrated in Figure 18(b) and Figure 18(c).

\section{Implications for prototype structures}

It is instructive to apply the findings reported here to a hypothetical prototype system. Modelling a typical $5 \mathrm{MW}$ wind turbine (NREL 5 MW reference Jonkman et al. (2009)) in approximately $25 \mathrm{~m}$ of water, the maximum load is calculated, considering an extreme operational gust. In this case a design moment, horizontal and vertical loading of $340 \mathrm{MNm}, 6 \mathrm{MN}$, $18 \mathrm{MN}$ respectively were assumed. It may be noted that these values are different from the operational loads.

For a typical European offshore site, the ground conditions can be approximated by a sand with an effective unit weight of

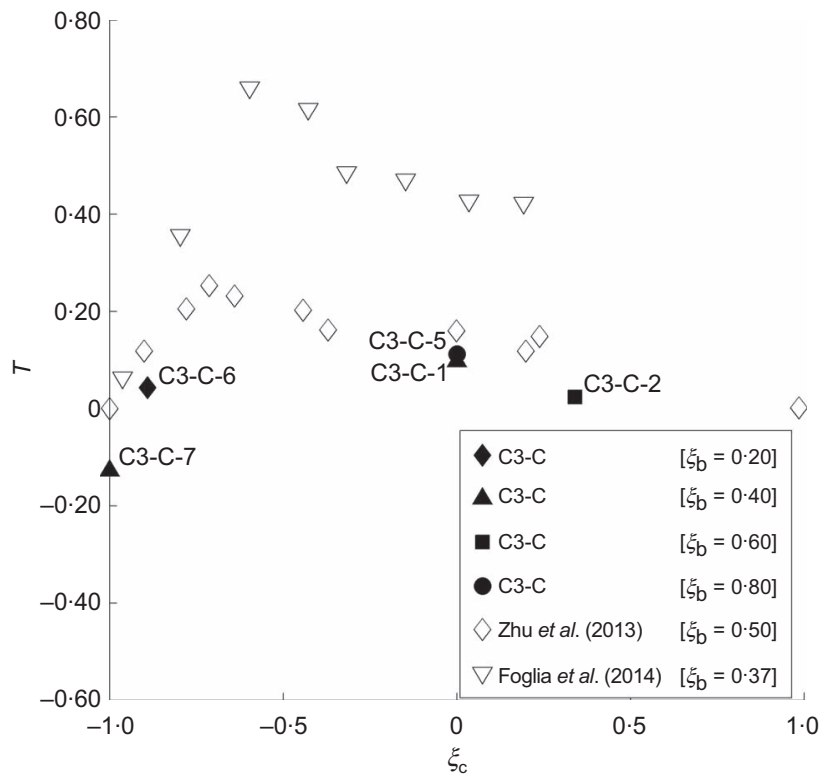

(a)

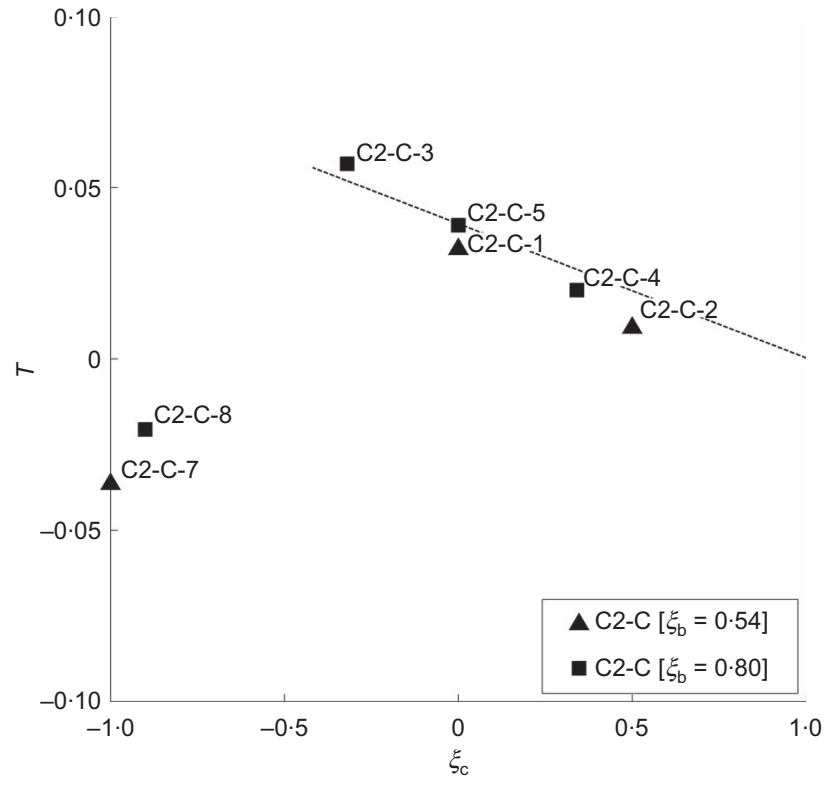

(b)

Figure 17 (a) Load directionality coefficient $T$, for the C3 caisson with the results of Zhu et al. (2013) and Foglia et al. (2014); (b) load directionality coefficient, $T$ for the $C 2$ caisson 


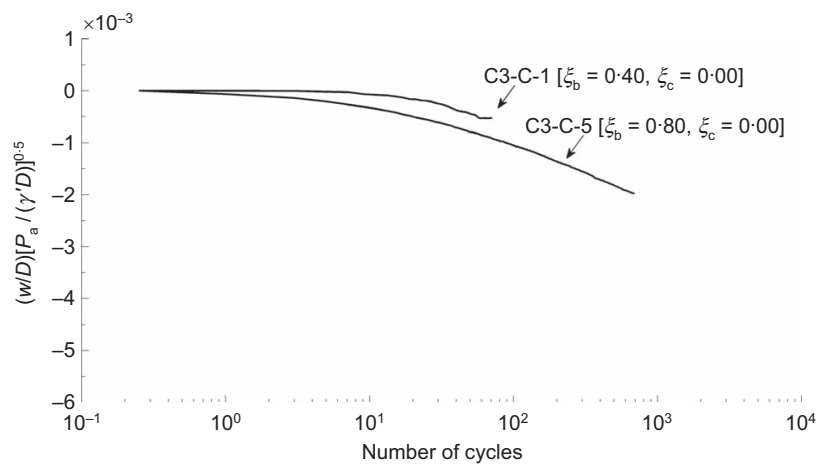

(a)

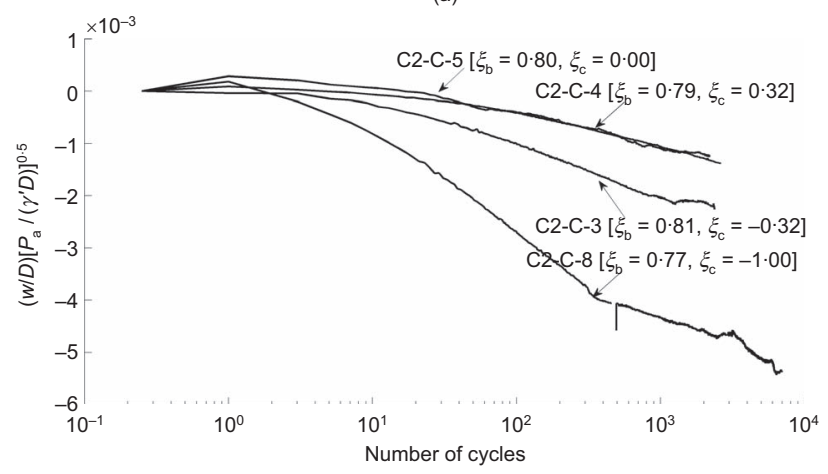

(c)

Figure 18 Caisson settlement with number of loading cycles:

(a) C3-C settlement $\xi_{\mathrm{c}}=0.0$; (b) C2-C settlement $\xi_{\mathrm{b}}=0.54$;

(c) C2-C settlement $\xi_{\mathrm{b}}=0.80$

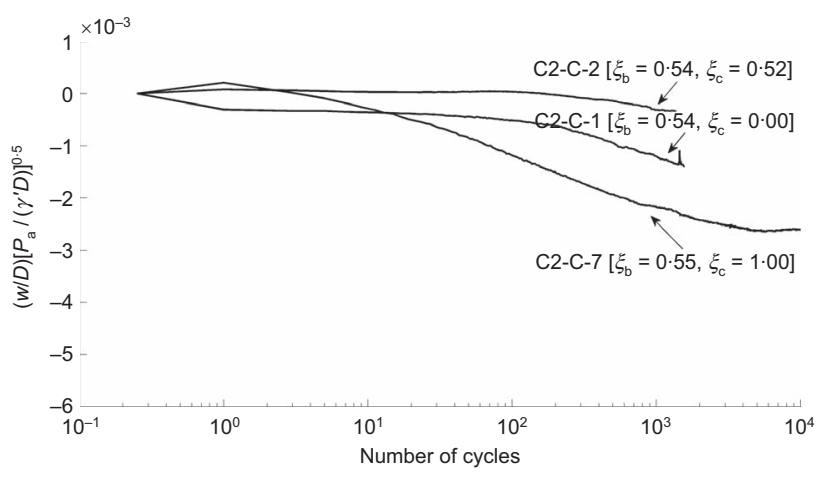

(b) $\gamma^{\prime}=9.7 \mathrm{kN} / \mathrm{m}^{3}$ and a friction angle of $\varphi_{\mathrm{cv}}=30^{\circ}$ (Bhattacharya et al., 2009; Kühn, 2001). Applying a factor of safety of 2 on the ultimate capacity as outlined in API RP 2A-WSD (American Petroleum Institute, 2007) and employing the design procedure described by Schakenda et al. (2011), a single caisson approximately $18 \mathrm{~m}$ in diameter with a skirt penetration depth of $18 \mathrm{~m}$ would be required. Under normal operation (defined as case 1.1 in British standards (BSI, 2009)), a cyclic moment in the range $140-220 \mathrm{MNm}$ was estimated to act upon the turbine. The maximum moment-carrying capacity has been estimated to be $880 \mathrm{MNm}$, which leads to a load capacity and direction factors of $\xi_{\mathrm{b}}=0.25$ and $\xi_{\mathrm{c}}=0.63$ respectively, obtained from Equations 1 and 2.

Calculating the accumulation of rotation for this case, a rotation coefficient of $T=0.0066$ can be interpolated (obtained from Figure 17(b) considering a loading directionality $\xi_{\mathrm{c}}=0.63$ ). If such a loading regime (cyclic moment of $140 \mathrm{MNm}$ and $220 \mathrm{MNm}$ ) were applied to a turbine for a period of 15 years $\left(\sim 4 \times 10^{7}\right.$ cycles $)$, a normalised nondimensional rotation of 1.29 can be obtained (using Equation 4). For the prototype turbine, considering a dimensional static rotation of $0.21^{\circ}$ (obtained from Figure 10), an accumulated rotation of $0 \cdot 30^{\circ}$ would be expected. Such a rotation would not be within the serviceability limits imposed on the design (Peire et al., 2009). However, for the same loading conditions ( $\xi_{\mathrm{b}}=$ 0.25 and $\xi_{\mathrm{b}}=0 \cdot 63$ ), a caisson with a diameter and penetration depth of $19 \mathrm{~m}$ would experience a reduced total accumulated rotation of $0.22^{\circ}$, which would lie within the serviceability limits.

Considering the same loading regime detailed above (cyclic moment of $140 \mathrm{MNm}$ and $220 \mathrm{MNm}$ ), an initial non-dimensional rotational stiffness of 107 has been estimated. This value is expected to increase by $25 \%$ after 15 years, based on Equation 3 and a stiffness change parameter $\left(A_{k}\right)$ of 1.52 obtained from this investigation. In practice however this is highly dependent on the current void ratio of the soil and its strain hardening characteristics (Bhattacharya et al., 2013). Using the dynamic model defined by Adhikari and Bhattacharya (2011), this would alter the first modal frequency of such a wind turbine from $0 \cdot 218 \mathrm{~Hz}$ to $0 \cdot 221 \mathrm{~Hz}$. Assuming the turbine is designed as a soft-stiff system (see Figure 2), such a change would have the effect of moving the modal frequency further away from the $1 \mathrm{P}$ 
International Journal of Physical Modelling in Geotechnics Volume 14 Issue 4
Centrifuge study on the cyclic performance of caissons in sand Cox, O'Loughlin, Cassidy et al. zone, causing a long-term benefit. Owing to the consistent stiffening response observed for different caisson geometries and various loading regimes, altering the caisson dimensions would not reduce the strain hardening characteristics of the local sand.

\section{Conclusion}

Considering the results presented in this paper it is possible to draw a number of conclusions about the investigation and the use of caissons as foundations for offshore wind structures. These conclusions are based on the practical maximum number of cycles that can be applied in a geotechnical centrifuge (given time and usage constraints). The tests in this investigation involved up to 12000 cycles, which is short of the $1 \times 10^{8}$ cycles that may potentially be applied to a turbine over its 20-year lifetime. Despite this limitation, clear trends and behaviours were identified from the tests as summarised below.

(a) The aspect ratio of the caisson has a significant effect on the foundation stiffness and its corresponding capacity. In the pushover tests not only was the caisson with a higher aspect ratio stiffer and stronger, but also displayed ductile behaviour. This behaviour can only be attributed to its increased embedment of the caisson changing the failure mechanism of the foundation.

(b) The rotational stiffness of the caisson system increased when subjected to cyclic loading under a fully drained condition. This increase was approximated by a logarithmic relationship, which was effected to some degree by the load orientation and load level. The increase in stiffness during long-term cyclic loading was much lower than previously reported for monopiles (LeBlanc et al., 2010a).

(c) Under the application of cyclic loading the suction caissons experienced an accumulation of rotation with increasing cycles under a fully drained condition. This rotation was dependent on the magnitude and relative directionality of the loading. In general a cyclic regime between one-way and two-way caused the greatest rotation, similar to the observations of LeBlanc et al. (2010a), Zhu et al. (2013) and Foglia et al. (2014).

(d) Some rotation was observed in the two-way loading tests where there was no predominant loading direction. This is believed to be due to the first quarter loading cycle creating differing soil conditions on opposite sides of the caisson, producing the conditions for one side to compact more than the other. This accumulation of rotation was independent of the load magnitude and is a feature that requires further investigation.

\section{Acknowledgements}

The research presented in this paper would not have been possible without the exemplary help from the World
Universities Network researcher mobility program. Specific thanks should go to Alan Champneys, Manuel Palacois, Dave Jones, John Breen, Shane DeCatilina and Khin Thida Seint without whose help this research would not have been possible. This work forms part of the activities of the Centre for Offshore Foundation Systems (COFS), currently supported as a node of the Australian Research Council Centre of Excellence for Geotechnical Science and Engineering and as a Centre of Excellence by the Lloyd's Register Foundation. Lloyd's Register Foundation invests in science, engineering and technology for public benefit, worldwide.

\section{REFERENCES}

Adhikari S and Bhattacharya S (2011) Vibrations of windturbines considering soil-structure interaction. Wind and Structures 14(2): 85-112.

American Petroleum Institute (2007) Recommended Practice for Planning, Designing and Constructing Fixed Offshore Platforms - Working Stress Design. American Petroleum Institute, Washington DC, USA.

Andersen KH, Murff JD, Randolph MF et al. (2005) Suction anchors for deepwater applications. In Frontiers in Offshore Geotechnics: ISFO (Gourvenec S and Cassidy MJ (eds)). Taylor \& Francis, Perth, Australia.

Bhattacharya S, Carrington T and Aldridge T (2009) Observed increases in offshore pile driving resistance. Proceedings of the Institution of Civil Engineers - Geotechnical Engineering 162(1): 71-80.

Bhattacharya S, Cox JA, Lombardi D and Muir Wood D (2012) Dynamics of offshore wind turbines on two types of foundations. Proceedings of the Institution of Civil Engineers - Geotechnical Engineering166(2): 159-169.

Bhattacharya S, Nikitas N, Garnsey J et al. (2013) Observed dynamic soil-structure interaction in scale testing of offshore wind turbine foundations. Soil Dynamics and Earthquake Engineering 54: 47-60.

BSI (2009) BE EN 61400-3: 2009. Wind turbines - Part 3: Design requirements for offshore wind turbines. BSI, London, UK.

Byrne BW (2000) Investigations of Suction Caissons in Dense Sand. PhD thesis, University of Oxford, Oxford, UK.

Carter JMF (2007) North Hoyle offshore wind farm: design and build. Proceedings of the Institution of Civil Engineers Energy 160(1): 21-29.

Cox JA and Bhattacharya S (2012) Dynamic stability of suction caisson founded offshore wind turbines. Proceedings of the Offshore Technology Conference, American Petroleum Industry (API), Houston, TX, USA, pp. 1-12.

Det Norske Veritas (2002) Guidelines for Design of Wind Turbines. Det Norske Veritas, Copenhagen, Denmark.

Det Norske Veritas (2010) Buckling Strength of Shells DNV-OSC202. Det Norske Veritas, Høvik, Norway. 
Centrifuge study on the cyclic performance of caissons in sand Cox, O'Loughlin, Cassidy et al.
Doherty JP, Houlsby GT and Deeks AJ (2005) Stiffness of flexible caisson foundations embedded in nonhomogeneous elastic soil. Journal of Geotechnical and Geoenvironmental Engineering 131(12): 1498-1508.

DTI (Department of Trade and Industry) (2001) Monitoring and Evaluation of Blyth Offshore Wind Farm-Projected Capital Costs of UK Offshore Windfarms Based on the Experience at Blyth. DTI, London, UK, DTI/Pub URN 01/1524.

DTI (2007) Study of the costs of offshore wind generation. $A$ Report to the Renewables Advisory Board and DTI. DTI, London, UK.

Dyson G (1999) Lateral Loading of Piles in Calcareous Sediments. PhD thesis, University of Western Australia, Crawley, Australia.

Feld T (2001) Suction Buckets, A New Innovative Foundation Concept, Applied to Offshore Wind Turbines. PhD thesis, Aalborg University, Aalborg, Denmark.

Foglia A and Ibsen LB (2013) A similitude theory for bucket foundations under monotonic horizontal load in dense sand. Geotechnical and Geological Engineering 31(1): 133142 .

Foglia A, Ibsen LB, Nicolai G and Andersen LV (2014) Observations on bucket foundations under cyclic loading in dense saturated sand. In ICPMG2014 - Physical Modelling in Geotechnics: Proceedings of the 8th International Conference on Physical Modelling in Geotechnics, Perth, Australia (Gaudin C and White D (eds)). CRC Press, Boca Raton, FL, USA, pp. 667-673.

Gaudin C, Clukey E, Garnier J and Phillips R (2010) New frontiers for centrifuge modelling in offshore geotechnics. Frontiers in Offshore Geotechnics II. CRC Press, Boca Raton, Florida, USA.

Hardin BO and Drnevich VP (1972) Shear modulus and damping in soils: Design equations and curves. Journal of the Soil Mechanics and Foundations Division, ASCE 98(7): 667-692.

Hoadley PJ, Barton YO and Parry RHG (1981) Cyclic lateral load on model pile in a centrifuge. Proceedings of the 10th International Conference on Soil Mechanics and Foundation Engineering, Stockholm, Sweden, pp. 621-635.

Houlsby GT, Ibsen LB and Byrne BW (2005) Suction caissons for wind turbines. In Proceedings of Frontiers in Offshore Geotechnics: ISFOG, Perth, Australia (Cassidy G (ed.)). Taylor \& Francis, London, UK.

Jonkman J, Butterfield S, Musial W and Scott G (2009) Definition of a 5-MW Reference Wind Turbine for Offshore System Development Golden. National Renewable Energy Laboratory, Golden, CO, USA.

Kelly RB, Houlsby GT and Byrne BW (2006) A comparison of field and laboratory tests of caisson foundations in sand and clay. Géotechnique 56(9): 617-626.

Klinkvort RT and Hededal O (2013) Lateral response of monopile supporting an offshore wind turbine. Proceedings of the Institution of Civil Engineers - Geotechnical Engineering 166(2): 147-158.

Klinkvort RT, Leth CT and Hededal O (2010) Centrifuge modelling of a laterally cyclic loaded pile. Physical Modelling in Geotechnics. Taylor \& Francis, Abingdon, UK.

Kühn M (2001) Dynamics and Design Optimisation of Offshore Energy Wind Conversion Systems. PhD thesis, Delft University of Technology, Delft, the Netherlands.

Kühn M, Bierbooms WAAM, Van Bussel GJW et al. (1998) OptiOWECS; Structural and Economic Optimisation of Bottom Mounted Offshore Wind Energy Convertors. JOULE III Project Vols 0-5. Delft University of Technology, Delft, the Netherlands.

Larsen JHM, Soerensen HC, Christiansen E, Naef S and Vølund P (2005) Experiences from Middelgrunden $40 \mathrm{MW}$ Offshore Wind Farm. Copenhagen Offshore Wind, Copenhagen, Denmark, Lyngby, Denmark.

LeBlanc C (2009a) The Monopod Bucket Foundation: recent experiences and challenges ahead. Proceedings of Hamburg Offshore Wind Conference 2009. GL Group, Hamburg, Germany. See http://www.gl-group.com/pdf/ No12_Bakmar.pdf (accessed 10/12/2014).

LeBlanc C (2009b) Design of Offshore Wind Turbine Support Structures. PhD thesis, Technical University of Denmark, Lyngby, Denmark.

LeBlanc C, Houlsby GT and Byrne BW (2010a) Response of stiff piles in sand to long-term cyclic lateral loading. Géotechnique 60(2): 79-90.

LeBlanc C, Houlsby GT and Byrne BW (2010b) Response of stiff piles to random two-way lateral loading. Géotechnique 60(9): 715-721.

Li Z, Haigh SK and Bolton MD (2010) Centrifuge modelling of mono-pile under cyclic lateral loads. Proceedings of the 7th International Conference on Physical Modelling in Geotechnics, Zurich, Switzerland, pp. 965-970.

Liingaard MA (2006) Dynamic Behaviour of Suction Caissons. PhD thesis, Technical University of Denmark, Denmark.

Lin S and Liao J (1999) Permanent strains of piles in sand due to cyclic lateral loads. Journal of Geotechnical and Geoenvironmental Engineering 125(9): 798-802.

Liu Q and Lehane B (2012) The influence of particle shape on the (centrifuge) cone penetration test (CPT) end resistance in uniformly graded granular soils. Géotechnique 62(11): 973-984.

Long J and Vanneste G (1994) Effects of cyclic lateral loads on piles in sand. Journal of Geotechnical Engineering 120(1): 225-244.

Lu X, Wu Y, Jiao B and Wang S (2007) Centrifugal experimental study of suction bucket foundations under dynamic loading. Acta Mechanica Sinica 23(6): 689-698.

O'Loughlin C and Lehane B (2003) Measure and Prediction of Deformation Patterns Beneath Strip Footings in Sand. Department of Civil and Resource Engineering, University 
of Western Australia, Perth, Australia, Research report no. $\mathrm{C}: 1751$.

Peire K, Nonneman H and Bosschem E (2009) Gravity based foundations for the Thornton Bank Offshore Wind Farm. Terra et Aqua 2009(115): 19-29.

Randolph MF and Wroth CP (1979) An analytical solution for the consolidation around a driven pile. International Journal for Numerical and Analytical Methods in Geomechanics 3(3): 217-229.

Randolph MF, Jewell RJ, Stone KJL and Brown TA (1991) Establishing a new centrifuge facility. In Proceedings International Conference Centrifuge 91, Boulder, CO, USA (Ko H-Y and Mclean FG (eds)). Balkema, Stockholm, Sweden, pp. 3-9.

Rosquoët F (2004) Pieux sous charge latérale cyclique. PhD thesis, University of Nantes, France (in French).

Sawicki A and Swidzinski W (1989) Mechanics of a sandy subsoil subjected to cyclic loadings. International Journal for Numerical and Analytical Methods in Geomechanics 13(19): 511-529.

Schakenda B, Nielsen SA and Ibsen LB (2011) Foundation Structure. United States of America patent application 12/ 226,255, February.
Senders M (2008) Suction Caissons in Sand as Tripod Foundations for Offshore Wind Turbines. PhD thesis, University of Western Australia, Crawley, Australia.

Tran MN (2005) Installation of Suction Caissons in Dense Sand and the Influence of Silt and Cemented Layers. PhD thesis, The University of Sydney, Sydney, Australia.

Verdure L, Garnier J and Levacher G (2003) Lateral cyclic loading of single piles in sand. International Journal of Physical Modelling in Geotechnics 3(3): 17-28.

Villalobos FA (2006) Model Testing of Foundations for Offshore Wind Turbines. PhD thesis, University of Oxford, UK.

Zaaijer MB (2009) Review of knowledge development for the design of offshore wind energy technology. Wind Energy 12(5): 411-430.

Zhang JH, Zhang LM and Lu XB (2007) Centrifuge modeling of suction bucket foundations for platforms under ice-sheetinduced cyclic lateral loadings. Ocean Engineering 34(8): $1069-1079$.

Zhu B, Byrne B and Houlsby GT (2013) Long-term lateral cyclic response of suction caisson foundations in sand. Journal of Geotechnical and Geoenvironmental Engineering 139(1): 73-83.

\section{WHAT DO YOU THINK?}

To discuss this paper, please email up to 500 words to the editor at journals@ice.org.uk. Your contribution will be forwarded to the author(s) for a reply and, if considered appropriate by the editorial panel, will be published as discussion in a future issue of the journal.

Proceedings journals rely entirely on contributions sent in by civil engineering professionals, academics and students. Papers should be 2000-5000 words long (briefing papers should be 1000-2000 words long), with adequate illustrations and references. You can submit your paper online via www.icevirtuallibrary.com/content/journals, where you will also find detailed author guidelines. 